\title{
Occupational Therapy in Children with Special Needs: Systematic Review
}

\author{
Ulul Azmi Asya, Huriati, Andi Adriana Amal, Arbianingsih \\ UIN Alauddin Makassar, Indonesia \\ Corresponding author: aulul828@gmail.com
}

\begin{abstract}
Background: Children with special needs are children who are significantly different from other children, they are physically, psychologically, cognitively and socially obstructed in achieving their goals and potential to the fullest such as autism.

Purpose: This study aimed to determine the provision of effective occupational therapy in children with special needs.

Methods: This research uses a quantitative descriptive design. Search for research articles in several databases using certain keywords in the period 2015-2019.

Results: Search results obtained 1396 articles using occupational therapy, there were only 10 articles that met the inclusion criteria analyzed using the Duffy's Research Appraisal Checklist Approach and the 10 articles included in the superior paper category so that it was good for further analysis. Based on the results of Systematic Review shows that effective occupational therapy is given to children with special needs (Autism). Occupational therapy given is very varied, namely drawing, collage technique, buttoning clothes, remembering pictures, sensory oral motor stimulation. Motor skills acquisition training, Equine-Assisted Therapy / EAT, Sensory Integration Therapy / SIT.

Conclusion: From the analysis of the article shows that all occupational therapy can help improve both physical and mental development in children with autism so that children with autism can carry out daily activities like children in general and improve their quality of life. Occupational therapy found in this review can be used as an intervention in overcoming Developmental problems in children with autism due to simple techniques using daily activities.
\end{abstract}

Keywords: Children with Special Needs, Autism, Occupational Therapy. 
Journal Of Nursing Practice

http://thejnp.org

ISSN: 2614-3488 (print); 2614-3496 (online)

Vol.3 No.2. April 2020. Page.268-278

\section{BACKGROUND}

Children with special needs are children who are significantly different from other children, they are both physically, psychologically, cognitively and socially obstructed in achieving their goals and potential optimally such as speech disorders, disability, mental reterdation and emotional disorders. The existence of children with special needs (ABK) in Indonesia can not be ignored, given the number of those who continue to grow in recent years because it is easier to find children with developmental disorders both physically, intellectually, emotionally, and socially in the middle of society (Mangunsong, 2009).

The number of children with special needs (ABK) in Indonesia from year to year continues to increase. The United Nations (United Nations) estimates that at least 10 percent of school-age children have special needs. The number of school-age children in Indonesia with special needs, which is 5-14 years, there are 42.8 million people. If you follow these estimates, it is estimated that there are approximately 4.2 million Indonesian children with special needs (Desiningrum, 2016).

According to the latest data, the number of children with special needs in Indonesia has reached 1,544,184 children, with 330,764 children (21.42\%) in the age range of 5-18 years. Of this amount, only 85,737 children with special needs are attending school, there are still 245,027 children with special needs who have not received education at school, either special schools or inclusive schools. The number of children with special needs in 2011 was recorded at 356,192 children, but those who received new services were 86,645 children and in 2012 only 105,185 children, in 2014 the government targeted at least 50\% of children with special needs to be accommodated (Desiningrum, 2016).

The application in educating children with special needs requires therapy that is useful to help them develop more physically and mentally. The therapy provided is expected to be able to stimulate the physical development of children well in order to be able to do things as done by children their age and be able to change the disruption of communication, social, and behavior development that occurs in children so as to produce positive behavior and be able to become an independent child (Irawan, 2016).

Therapy is used for children with special needs by applying occupational therapy or often called occupational therapy. Apart from being used for children with special needs, this therapy can also be given to children / adults who have learning difficulties, motor disabilities (injuries, strokes, traumatic brain injuries), autism, sensory processing disorders, down syndrome, Attention Deficit Hyperactivity Disorder (ADHD), genetic disorders, asperger's syndrome, speech delay, developmental disorders (Cerebal Palsy), Pervasive Developmental Disorder (PDD) and those with psychiatric disorders.

Children with special needs usually have difficulty doing things that other children have no difficulty doing, for example writing or cutting. Occupational therapy can be used as an option to work to improve children's physical and mental abilities to participate in activities involving gross and fine motor children so that children can be independent and can be developed and accepted in the community Occupational therapy aims to assist children in developing strength and coordination of the brain, and helps children who have problems with fine motor skills (E Kosasih, 2012).

In this study, researchers want to explain further how the effectiveness of occupational therapy given to children with special needs by using systematic review as an analysis tool. 


\section{OBJECTIVE}

This study aimed to determine the provision of effective occupational therapy in children with special needs.

\section{METHODS}

This research uses a quantitative descriptive design with a systematic review approach. The total number of journals obtained totaled 1396 journals, the source of the journals in this study using the Google Scholar database with 475 journals, Emerald with 255 journals, Garuda Portal with 14 journals, Oxford with 515 journals, and IJSR with 155 journals, using keywords:

In choosing a research journal, the inclusion criteria are articles published in the last 5 years, 2015-2019, fulltext articles that fit the research objectives, namely occupational therapy in children with special needs, there are ISSN, DOI or volume, and limits of experimental research for children with special needs (Autism)

Then all of the articles were selected according to the inclusion and exclusion criteria and then the relevance was selected using Duffy's Research Appraisal Checklist Approach. Only 10 who met the inclusion criteria were analyzed using the Duffy's Research Appraisal Checklist Approach and 10 of the articles included in the superior paper category (205-306).

\section{RESULTS}

1. Characteristics of Respondents

Tabel 1. Characteristics of Respondents

\begin{tabular}{lcccc}
\hline \multirow{2}{*}{ Occupational Therapy } & \multicolumn{2}{c}{ Age } & \multicolumn{2}{c}{ Gender } \\
\cline { 2 - 5 } & Pre School & School & Male & Female \\
\hline Draw & $\sqrt{y y y y}$ & $\sqrt{ }$ & $\sqrt{ }$ & $\sqrt{ }$ \\
Collage Technique & & $\sqrt{ }$ & $\sqrt{ }$ & $\sqrt{ }$ \\
Put on shirt buttons & & $\sqrt{ }$ & $\sqrt{ }$ & $\sqrt{ }$ \\
Remembering Figs & & $\sqrt{ }$ & $\sqrt{ }$ & $\sqrt{ }$ \\
Acquisition Skills Training & & $\sqrt{ }$ & $\sqrt{ }$ & $\sqrt{ }$ \\
Oral Motor Sensory & $\sqrt{ }$ & $\sqrt{ }$ & $\sqrt{ }$ & $\sqrt{ }$ \\
Sensory Integration Stimulation & $\sqrt{ }$ & $\sqrt{ }$ & \\
Equine-Assisted Therapy & & & $\sqrt{ }$
\end{tabular}

2. Occupational Therapy obtained

a. Of the 10 articles found 3 articles that use occupational therapy drawing on children with special needs in this case autistic.

b. Of the 10 articles obtained 1 article that uses occupational therapy collage techniques in children with special needs in this case autistic.

c. Of the 10 articles obtained 1 article that uses occupational therapy considering drawing in children with special needs in this case autistic.

d. Of the 10 articles obtained 1 article that uses occupational therapy buttoning clothes on children with special needs in this case autistic.

e. Of the 10 articles obtained 1 article that uses occupational therapy acquisition skills training in children with special needs in this case autistic. 
f. Of the 10 articles obtained 1 article that uses oral sensory stimulation motor occupational therapy in children with special needs in this case autism.

g. Of the 10 articles obtained 1 article that uses occupational therapy sensory integration therapy / SIT in children with special needs in this case autistic.

h. From 10 articles obtained 1 article that uses Equine-Assisted Therapy occupational therapy in children with special needs in this case autistic

3. Occupational Drawing Therapy

a. The duration of occupational therapy draws 30 minutes during one therapy

b. The procedure for providing occupational therapy is drawing the first step to measure the level of development (motor and independence) before being given occupational therapy. Then given occupational therapy drawing and coloring pictures that have been made. Furthermore, measurement of the level of development of autistic children is repeated.

4. Occupational therapy collage techniques

a. The duration of occupational therapy with a collage technique is around 15-20 minutes

b. The procedure for providing occupational therapy with a collage technique with stages, first: maintaining the comfort and privacy of children. Second: provide intervention by having the child tear the colored paper (origami) and stick it on a predetermined image. The third stage, the evaluation stage by observing the results that have been done by children in terms of sticking colored paper in a predetermined image

5. Occupational therapy remembering images

a. The duration of occupational therapy is given a picture of 20-25 minutes

b. The procedure for providing occupational therapy is to remember the picture, which is to first measure the level of cognitive development before giving occupational therapy. Then given occupational therapy given the picture. After that, measuring the level of cognitive development in autistic children is repeated.

6. Occupational therapy buttoning a shirt

a. The duration of occupational therapy buttoning the shirt is about 15-20 minutes

b. The procedure for giving occupational therapy buttoning a shirt is to first measure the level of fine motor development before being given occupational therapy. Then the occupational therapy buttoned the shirt with props of one buttoned shirt. After that, the level of fine motor development in the autistic child is measured again.

7. Occupational therapy acquisition skills training

a. The duration of occupational therapy acquisition skills training is 1 hour 15 minutes in 1 therapy session. The number of sessions given was 36 sessions in a week given 3 sessions.

b. The procedure for providing occupational therapy for acquisition skills training is to provide acquisition interventions. After data collection, the test is carried out using the Test of Gross Motor Development (TGMD-2)

8. Oral motor occupational sensory stimulation therapy

a. The duration of oral occupational therapy of motor sensory stimulation is for 20 minutes to 25 minutes. 
b. The procedure for providing oral motor sensory stimulation occupational therapy is to first use the Repetitive Behavior Scale Revised (RBS) measurement, then to be given oral motor sensory stimulation occupational therapy. After that the measurement of RBS was performed again on the child.

9. Occupational therapy sensory integration therapy / SIT

a. The duration of occupational therapy for sensory integration therapy / SIT is 45 minutes with an additional 15 minutes devoted to providing education to parents.

b. The procedure for providing occupational therapy with sensory integration therapy / SIT, which is screening first using Sensory Profile (SP), is used to assess sensory problems. After that the sensory integration therapy / SIT occupational therapy intervention was given. Then a measurement using The Short Child Occupational Profile (SCOPE) is used to compare the two groups in terms of changes in their work performance.

10. Equine-Assisted Therapy occupational therapy

a. The duration of Equine-Assisted Therapy is 60-70 minutes

b. Procedure for providing occupational therapy with Equine-Assisted Therapy with each subject evaluated at 30 days before the start of the EAT session using the Vineland Adaptive Behavior Scale (VABS) and within 30 days after the end of the EAT session using Tower of London (TOL) measurements

\section{DISCUSSION}

1. Draw

Based on the results of the analysis of occupational therapy drawing proved effective in increasing gross motor skills in children with special needs in this case autistic. Based on research results prove that drawing occupational therapy can improve gross motor skills thereby increasing the quality of life in children with autism.

The drawing function for autistic children physically (motor) can help the process of controlling the hands and fingers and train the muscles of the hand, sensory help focus visual attention respond to sensory input, communication can help the development of expression and emotion, cognitive can help stimulation mental and problem-solving abilities for example in the selection of color images, and socially and emotionally can help self-confidence to complete tasks and adjust actions and feelings in an image expression (Safaruddin, 2015)

One of the factors that influence the fine motor skills of children is the pattern of parenting and family, such as the family environment is very important in providing guidance to children in carrying out daily actions so as to be able to express the desires they have in an attempt to heal someone with mental disorders. and can provide an active activity by providing therapy that exercises subtle movements of the hand and integration of basic movements that have been mastered through drawing (Sugiono, 2003).

2. Collage Technique

Based on the results of the analysis of occupational therapy, collage techniques have proven to be effective in increasing fine motor skills in children with special needs, in this case autism. In this article assessing fine motor skills by observing the activities of 


\section{Journal Of Nursing Practice}

http://thejnp.org

ISSN: 2614-3488 (print); 2614-3496 (online)

Vol.3 No.2. April 2020. Page.268-278

children with autism glue members in the picture, taking grain and sticking grain in the image then proceed with the activity of filling the picture. This is in line with research Herviani (2017) which says that three-dimensional collage activities can be applied in improving fine motor skills in children with autism.

Collage according to Muharrar and Verayanti (2013) is a technique of sticking various elements into one frame so that it produces new works of art. One of the benefits of collage technique is to train a child's motor skills, the activity of collage emphasizes the activities of hand movements, where it is able to train to develop children's fine motor skills. Individuals with autism disorder find it easier to obtain information visually. Seeing the learning characteristics of autistic children who tend to visual learning, then in the treatment of using three-dimensional collage activities that in the process of demonstrating or modeling directly to students, so students can directly pay attention and afterwards practice according to what children see (Nirahma \& Yuniar, 2012 ).

3. Buttoning the Shirt

Based on the results of occupational therapy analysis buttoning the clothes proved effective in increasing gross motor skills in children with special needs in this case autistic. Based on the results of research prove that occupational therapy buttoning a shirt can improve fine motor skills thereby increasing the quality of life in children with autism.

The above research results are in accordance with research conducted by (Marginingsih, 2012) someone who has good fine motor skills will facilitate activities in school, home and daily work such as fishing clothes, holding spoons and forks, the more mature development of the nervous system regulate muscles.

The benefits of fine motorbutton buttons training include training the ability of fingers, coordination between hands, eyes and brain (Anna, 2011). With the practice of buttoning a child, children can enjoy the exercise and mastery of many skills in a sense of calm, concentration, cooperation, discipline and confidence in oneself (Sadisah, 2012).

4. Remembering Pictures

Based on the results of occupational therapy analysis, remembering images have proven to be effective in increasing cognitive abilities in children with special needs, in this case autistic. When occupational therapy is given the therapist trains the child's skills in a pleasant atmosphere while inviting children to play so as to arouse interest in practicing. The therapy is given not too long but often and the therapist will stop it if the child looks bored.

An autistic child has a characteristic in learning that is easy to understand and remember various things that are touched (visual learner or visual thinking), easy to understand various things that he experiences (hands on learner) therefore the use of assistive devices using visual strategies (assistive devices) visual) can be used in teaching communication skills. This is in agreement with Gemah (2004) who said that many children with autism get better results when learning by using visual (vision). 


\section{Journal Of Nursing Practice}

http://thejnp.org

ISSN: 2614-3488 (print); 2614-3496 (online)

Vol.3 No.2. April 2020. Page.268-278

Visual learning makes it easy for children with autism to be able to concentrate and understand things, one of which is by seeing concrete objects, color photos, images or symbols. One visual strategy that can be used in bridging the communication limitations of autistic children is with occupational therapy considering images. Remembering images can also be a method used in helping non-verbal autistic children communicate. Remembering the image emphasizes the understanding and communication skills of children with autism through images. The images used are simple images, designed to follow general standards, do not differentiate between sexes, one image can be used for several functions and is easy to understand.

The use of occupational therapy, remembering pictures as a method or visual strategy is expected to help children with autistic verbal communication so that they can communicate and even help them to speak or use sound.

5. Acquisition skills training

Based on the results of occupational therapy analysis Acquisition skills training proved to be effective in increasing gross motor skills in children with special needs in this case autistic. Based on research results prove that occupational therapy acquisition skills training can improve gross motor skills thereby increasing the quality of life in children with autism.

Acquisition training is a procedure in training motor skills, motor development and motor control. The process that allows a child to solve movement problems to complete daily functional tasks in the fields of self care, school, play, mobility and communication. This research is supported by the effects of movement education programs by using movement patterns to develop basic motor skills in children, (Waffa Abd Elhafez Abd Elmaksoud Ghaly, 2010).

Acquisition skills training amounted to 36 sessions consisting of various activities namely balance activities, jumping and prancing, hand and eye coordination, core strength, general strength, planning and sensory motor.

6. Sensory Motor Oral Stimulation

Based on the results of the analysis of occupational therapy Sensory Motor Oral Stimulation proved effective in self-biting behavior in autistic children. Based on research results prove that occupational therapy Sensory Motor Oral Stimulation can stimulate oral motor in children with autism so as to prevent autistic children from biting themselves in expressing their emotions.

Sensory oral motor stimulation is a technique used to increase stimulation of the tongue and lips to prevent children from biting themselves. Biting yourself is a way for children with autism to get a stimulus and express their emotions.

As we all know biting is a way of self-seeking stimulus and expressing emotions for children with autism. This strange behavior at times can be self-injured and repetitive. There are various other behavioral problems that can arise over time such as irritation, anger and tantrums. 


\section{Journal Of Nursing Practice}

http://thejnp.org

ISSN: 2614-3488 (print); 2614-3496 (online)

Vol.3 No.2. April 2020. Page.268-278

This is in accordance with research Melisa (2009) who evaluated "The effect of sensory integration interventions on reducing maladaptive behavior in high school students with autism. He chose a 16 year old student. Sensory integration interventions were given 20 to 60 minutes, 3 times a week at 2 week interventions The results show that there is a reduction in maladaptive behavior through sensory integration interventions.

7. Sensory Integration Therapy / SIT

Sensory Integration Therapy / SIT is a type of therapy that prioritizes the organization of sensations. The purpose of this therapy is so that the brain can integrate information that comes from the senses so that the body can act and respond in accordance with the environmental situation at hand and with a purposeful manner.

In SIT therapy in addition to direct intervention for children, Therapists also provide strategies that target the sensory needs of children for caregivers or for the parents by providing information about approaches to interact with children.

Sensory integration therapy is widely used for the management of children with developmental, learning, and behavior disorders as in the research of Rusiana states that the application of the sensory integration approach can minimize hyperactive behavior in autistic children in SLB Putra Mandiri Surabaya (Rusiana.E, 2013). As well as Fitri's research (2018) which analyzes the integration sensory therapy carried out in single children to see the function of the five senses (sight, smell, hearing, taste, and touch) through the involvement of parents and the environment states that there are changes in the development of independence salama following sensory integration therapy .

Sensory integration therapy as a form of occupation and treatment in children with certain conditions is often used as a way to make improvements, both to repair developmental disorders or learning disorders, social interaction disorders, and other behaviors. The purpose of holding sensory integration therapy is to restore the function of the five senses (sight, smell, hearing, taste, touch) and proprioceptive and vestibular. With the return of the five senses and the proprioceptive and vestibular functions, children can conduct self-development activities independently and reduce their sense of dependence on others (IDAI (Indonesian Pediatrician Association), 2011).

8. EAT / Equine-Assisted Therapy

EAT / Equine-Assisted Therapy or more commonly called Therapeutic riding is a therapy specifically for children with special needs (ABK) who use horses in therapeutic activities to bring about improvements in cognitive, physical, emotional, and social well being someone with disabilities (pathintl) .org)

At this EAT children are encouraged to follow instructions given by the therapist and to interact with the horse both verbally and not verbally. The usual activities carried out every one therapy session are usually divided into three parts; pre on horse, on horse, post on horse. Before riding or riding a horse the child is guided for grooming or 


\section{Journal Of Nursing Practice}

http://thejnp.org

ISSN: 2614-3488 (print); 2614-3496 (online)

Vol.3 No.2. April 2020. Page.268-278

cleaning and preparing the horse. In this section children are expected to form strong bonding with their horses.

Riding programs are known to be able to build self-confidence, self-esteem, and selfawareness when someone with disabilities has the motivation to ride and they have a feeling of pride in the activities carried out. In therapeutic riding therapy, horses help ABK physically and mentally by 'challenging' them to achieve something that seems impossible for someone with a disability to do. This is one reason why this therapy can build a child's confidence.

Apart from horses, other pets also make children dare to start new relationships, increasing the desire to join a group. In addition, it is also known from a study that children who have pets are better at introducing themselves to others, providing better information, and giving more response if invited to interact. The relationship that occurs between children and pets can foster empathy and sympathy in children (Etika, 2017).

This occupational therapy is very helpful in developing independence, as well as increasing the focus or concentration of children with autism in learning. The goal of occupational therapy for children with autism spectrum disorders is to improve their quality of life, both at home and at school.

\section{CONSLUSION}

Based on the results of Systematic Review shows that effective occupational therapy is given to children with special needs (Autism). Occupational therapy given is very varied, namely drawing, collage technique, buttoning clothes, remembering pictures, sensory oral motor stimulation. Motor skills acquisition training, Equine-Assisted Therapy / EAT, Sensory Integration Therapy / SIT. From the analysis of the article shows all occupational therapy can help improve both physical and mental development in children with autism so that children with autism can carry out daily activities like children in general and improve their quality of life

Occupational therapy found in this review can be used as an intervention in overcoming developmental problems in children with autism because the technique is simple using daily activities.

\section{SUGGESTION}

Based on the results of the Systematic Review that has been done about occupational therapy in children with special needs this therapy should be used as therapy to improve the physical and mental abilities of children with autism. It is also necessary to do training and guidance on occupational therapy for child nurses to have new skills to develop and socialize to the community.

\section{REFERENCES}

Anna, Lusia Kus. (2011). Latihan motorik halus dengan mengancingkan baju. Di unduh $\begin{array}{llll}\text { pada } & \text { tanggal } & 13 & \text { Agustus }\end{array}$ 
http://health.kompas.com/read/2011/05/02/10070730/Latih.Motorik.Halus.dengan .Mengancingkan.Baju..

Borgil, Marta, Dkk. (2015). Effectiveness of a Standardized Equine-Assisted Therapy Program For Children with Autism Spectrum Disorder. USA: Springer Science+Business Media New York.

Desiningrum, Dinni Ratri. Psikologi Anak Berkebutuhan Khusus. Yogyakarta: Psikosain. (2016).

Etika, Nimas Mita. (2017). Terapi anak autismen dengan hewan peliharaan. Diunduh pada tanggal 14 Agustus 2019 https://hellosehat.com/pusat-kesehatan/autisme/terapianak-autisme-dengan-hewan-peliharaan/.

Evi \& Tri Riska. (2015).Terapi Okupasi Perkembangan Motorik Halus Anak Autisme. Jurnal Ipteks Terapan. Sekolah Tinggi Ilmu Kesehatan Fort De Kock.

Herviani, Vivi Kurnia. (2017).Kegiatan Kolase Tiga Dimensi Terhadap Kemampuan Motorik Halus Anak Autis di TK. Universitas Negeri Surabaya (UNESA): Jurnal Pendidikan Khusus.

IDAI (Ikatan Dokter Anak Indonesia). (2011) Pedoman Pelayanan Medis Ikatan Dokter Anak Indonesia (1st ed.). indonesia: Badan Penerbit Ikatan Dokter Anak Indonesia. https://www.academia.edu/9082974/IKATAN_DOKTER_AN AK_INDONESIA_2011_PEDOMAN_PELAYANAN_MEDIS_IK ATAN_DOKTER_ANAK_INDONESIA_Edisi_II .2011.

Iqbal, Dkk. (2018). Efektivitas Pemberian Terapi Okupasi Dalam Meningkatkan Kemandirian Makan pada Anak Usia Sekolah Dengan Autis. Universitas Riau: Jurnal Keperawatan Sriwijaya.

Irawan, Ria Dewi. (2016).Terapi Okupasi (Occupational Therapy) Untuk Anak Berkebutuhan Khusus (Down Syndrome) (Studi Kasus Pada Anak Usia 5-6 Tahun Di Balai Pengembangan Pendidikan Khusus Semarang. Semarang: UNNES.

Jay, Dkk. (2015). Effectiveness of Sensory Motor Oral Stimulation for Reducing the Self Biting Behavior in Children With Autism. JKKMMRF College Of Occupational Therapy, Komarapalayan: IJSR.

Jordiono, Dkk. (2016). Pengaruh Terapi Okupasi Menggambar Terhadap Kemampuan Motorik Halus Anak Autis di SLB Negeri Semarang. Jurnal Ilmu Keperawatan STIKES Telogerejo Semarang.

Komariah, Fitri. (2018).Program Terapi Sensori Integrasi Bagi Anak Tunagrahita di Yayasan Miftahul Qulub. Jurnal of Disability Studies. Vol. V, No. 1, Januari-Juni 2018, h. 45-72. UIN Sayarif Hidayatullah.

Kosasih, E. (2012).Cara Bijak Memahami Anak Berkebutuhan Khusus. Bandung: Yrama Widya.

Nirahma, Choirunisa. (2012).Metode Dukungan Visual Pada Pembelajaran Anak dengan Autisme. Jurnal Psikologi Klinis dan Kesehatan Mental. Vol 1, No. 02, Juni 20.

Mangunsong. (2009). F. Psikologi dan Pendidikan Anak Berkebutuhan Khusus Jilid I. Jakarta: Lembaga Pengembangan Sarana Pengukuran dan Pendidikan Psikologi (LPSP3) Kampus Baru UI, Depok.

Muharrar, Syakir \& Sri Verayanti. (2013).Kreasi Kolase, Montase, Mozaik Sederhana. Jakarta: Esensi. 
R. Renuchitra, Dkk. (2016).Effect of Motor Skils Acquisition Training on Gross Motor Skilis of Autistic Children. India: Research Scholar, Department of Rehabilitation Sciences, Hollycross Collage.

Renetal. Watling, Jean Dietz. (2007). Immediate Effect of Ayres's Sensory IntegrationBased Occupational Therapy Intervention on Children With Autism Spectrum Disorders. The American Journal of Occupational Therapy Journal Volume 61, Number 5.

Rusiana.E. (2013). Pendekatan Sensori Integrasi Untuk Meminimalisasi Perilaku Hiperaktif Pada Anak Autis. Jurnal Pendidikan Khusus, 3, 1-10.

Safaruddin, Muhammad Sigid. (2015). Terapi Menggambar Buat Anak Spesial. Diunduh $\begin{array}{llll}\text { pada } & \text { tanggal } & 21 & \text { Agustus }\end{array}$ https://www.kompasiana.com/sigid/5500b0d8813311491bfa7cb6/terapimenggambar-buat-anak-special-autis

Wafaa Abd Elhafez Abd Elmaksoud Ghaly. (2010).The Effect of Movement Education Program by Using Movement Pattern to Develop Fundamental Motor Skills for Children Pre-School. World Journal of Sport Sciences 3. 